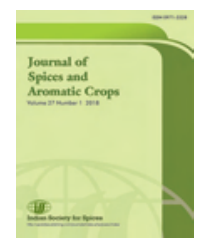

\title{
Air layering in cinnamon (Cinnamomum verum L.) under wet humid tropical conditions
}

\author{
A A Waman* \& P Bohra \\ Division of Horticulture and Forestry, \\ ICAR-Central Island Agricultural Research Institute, Port Blair-744 101, Andaman \& Nicobar. \\ *E-mail: ajit.hort595@gmail.com
}

Received 08 April 2017; Revised 07 March 2018; Accepted 26 March 2018

\begin{abstract}
Cinnamon is a cross pollinated species and seed propagation has resulted in development of considerable variability in growth, yield and quality among the populations. Air layering has been considered as one of the efficient methods of multiplication in cinnamon. However, the success of layering varies greatly depending on the local environmental conditions. In the present investigation, air layering was performed at 20 days interval during rainy season (July $3^{\text {rd }}$ to October $11^{\text {th }}$ ) of two consecutive years in Bay islands. Result revealed that first week of July was the most suitable time for air layering in cinnamon as it supported better rooting percentage $(87.5 \%)$.
\end{abstract}

Keywords: Propagation; Season; Spice crop; Tropical islands

Cinnamon (Cinnamomum verum L.) or dalchini is one of the ancient tree spices grown in India. Though both bark as well as leaves are known to possess aromatic components mainly cinnamaldehyde and eugenol, the bark of this species is valued as a spice. It has been used in the form of dried bark, bark powder, oil and oleoresins. Cultivation of this spice in India is mainly confined to States of Andaman and Nicobar Islands, Kerala, Karnataka, North Eastern India and parts of Tamil Nadu and Maharashtra. Combined estimate of cinnamon and tejpat suggests that in India, it's being grown on 2,770 ha area with about $5,050 \mathrm{t}$ production (Indian Horticulture Database 2014). However, the production is not enough to meet the domestic demand and hence, cinnamon is being imported from other countries of the world (Indian Spices 2016). Increasing the productivity through development and adoption of improved technologies is a key factor in reducing the dependence on import.

Soil and climatic conditions of the Andaman and Nicobar Islands are well suited for the cultivation of cinnamon (Parthasarathy et al. 2009) and presently it is cultivated in about 150 ha yielding $40 \mathrm{t}$ annually. Quality of cinnamon is assumed to be the finest in the islands compared with other parts of the country (Singh \& Sankaran 2012). Large availability of interspaces in the coconut and arecanut plantations in the Andaman and Nicobar 
Islands could be successfully utilized for its cultivation (Waman et al. 2016). However, existing plantations in the islands are of seedling origin. One can easily notice variations in cinnamon seedlings for leaf size, shape and colour of new flush, apart from the distinct chemotypes (Krishnamoorthy et al. 1988). Ergo, considerable variability is noticed in the yields and quality of the final produce and hence, vegetative propagation is of interest (Rema et al. 1997). The present report concerned an effort to identify the most appropriate time for carrying out air layering under island condition.

The present investigation was carried out in the Division of Horticulture and Forestry of ICAR- Central Island Agricultural Research Institute, Port Blair, Andaman and Nicobar Islands during 2015 and 2016. The islands exhibit typical tropical climate with average temperature of $18-31^{\circ} \mathrm{C}$ and annual rainfall of 3,100 mm distributed over May to December. Further, the relative humidity ranges between $60-90 \%$ in a year, while the average lies near to $70-80 \%$.

For layering, healthy shoots of $25-30 \mathrm{~cm}$ length and 1.0-1.5 cm thickness were selected. Leaves and small branches near the ringing area on selected shoots were removed and two circular cuts were given to the shoots for removing a ring of bark of about an inch width.
Commercial formulation of rooting hormone (Lipsa, Kolkata) was used for root induction and ringed portion was covered with soil: farmyard manure (1:1) before wrapping with polythene $(20 \mathrm{~cm} \times 20 \mathrm{~cm})$. Experiment consisted of six treatments i.e. $\mathrm{T}_{1}$ : layering on July $3, \mathrm{~T}_{2}$ : layering on July $23, \mathrm{~T}_{3}$ : layering on August 12, $\mathrm{T}_{4}$ : layering on September 1, $\mathrm{T}_{5}$ : layering on September 21 and $\mathrm{T}_{6}$ : layering on October 11. Experiment was laid out in completely randomized design with 20 layers in each treatment. Various parameters were recorded at the time of separation (90 days after layering) and data was subjected to analysis of variance using Web Agri Statistical Package 2.0 (WASP 2.0, ICAR-RC for Goa, Ela, India).

Air layering was performed for six times during rainy season under island condition. Generally, rooting process is facilitated by the rains (Ranaware et al. 1995) and hence, the dry periods in the islands were avoided during the experimentation. Pooled analysis of two years data revealed that percentage root induction varied between $35.0 \%$ and $87.5 \%$ amongst the treatments studied (Table 1). Maximum rooting percentage was obtained in layers done on $3^{\text {rd }}$ July $(87.5 \%)$ followed by those done on $23^{\text {rd }}$ July, while it was the lowest in layering performed on $21^{\text {st }}$ September. Though rooting response varied considerably during different seasons, the mean number of primary roots per layer did not vary significantly (Table 1 ).

Table 1. Air layering in cinnamon under Andaman condition as affected by time of layering (pooled data of two years)

\begin{tabular}{lcccc}
\hline Treatment & $\begin{array}{c}\text { Rooting } \\
\text { percentage }\end{array}$ & $\begin{array}{c}\text { Number of } \\
\text { primary roots } \\
\text { layer }\end{array}$ & $\begin{array}{c}\text { Mean length } \\
\text { of primary } \\
\text { root (cm) }\end{array}$ & $\begin{array}{c}\text { Mean thickness } \\
\text { of primary } \\
\text { root (mm) }\end{array}$ \\
\hline July 3 & 87.5 & $5.8 \mathrm{a}$ & $5.52 \mathrm{~b}$ & $2.74 \mathrm{a}$ \\
July 23 & 57.5 & $4.2 \mathrm{a}$ & $7.37 \mathrm{a}$ & $2.33 \mathrm{a}$ \\
August 12 & 47.5 & $4.2 \mathrm{a}$ & $5.18 \mathrm{bc}$ & $2.04 \mathrm{a}$ \\
September 1 & 50.0 & $3.7 \mathrm{a}$ & $8.53 \mathrm{a}$ & $2.17 \mathrm{a}$ \\
September 21 & 35.0 & $5.3 \mathrm{a}$ & $3.60 \mathrm{c}$ & $2.15 \mathrm{a}$ \\
October 11 & 43.2 & $3.8 \mathrm{a}$ & $4.00 \mathrm{bc}$ & $2.20 \mathrm{a}$ \\
\hline
\end{tabular}

${ }^{*}$ Means followed by same alphabet in a column do not differ significantly at $5 \%$ level of significance using least significant difference 
Length of longest root varied significantly amongst the studied treatments (Table 1). Maximum length of primary root was observed in propagules obtained from cinnamon layered on $1^{\text {st }}$ September $(8.5 \mathrm{~cm})$, which remained on par with layers of $23^{\text {rd }}$ July. Similar to rooting percentage, length of root was found to be the lowest $(3.6 \mathrm{~cm})$ in layers of $21^{\text {st }}$ September batch. Thickness of root ranged from 2.04 to $2.74 \mathrm{~mm}$; however, the differences were non-significant amongst the treatments studied.

Similar to present communication, significant variations for rooting response and growth parameters have been reported from different agro-ecological regions of the country viz., West Bengal (Banerjee et al. 1982), Karnataka (Hegde et al. 1989) and Maharashtra (Ranaware et al. 1995). These reports have suggested the positive effects of rainy period on layering success; however, the raining season and pattern vary significantly in different regions and hence, location specific studies are required. As no reports are available for island conditions, present study was conducted. The prevalence of optimum microclimate during the part of the year would possibly have helped in maximizing the rooting success. Rema et al. (1997) reviewed different propagation methods in spice crops in which they supported the possible role of endogenous auxins, sugars and other biochemical constituents in variable rooting success during different seasons.

It could be concluded that first week of July is the most suitable time for carrying out air layering under Andaman and Nicobar Islands condition. This technique being easier, farmers can easily multiply superior types in large number. In addition, inputs required for the purpose are easily available at cheaper cost and hence, it could be a boon for on farm production of quality planting material in the Andaman Islands.

\section{Acknowledgements}

Authors are thankful to the Director of the Institute for providing necessary facilities for conducting the experiment.

\section{References}

Banerjee D P, Chatterjee B K \& Sen S 1982 Air layering of cinnamon (Cinnamomum zeylanicum). South Indian Hort. 30: 272-273.

Hegde K P, Sulikeri G S \& Hulamani N C 1989 Effect of growth regulators and pre-girdling treatments on rooting of cinnamon air layers. South Indian Hort. 37: 329-332.

IHD 2014 Indian Horticulture Database, National Horticulture Board, Gurgaon, India, 286 p.

Indian Spices 2016 http://indianspices.com/sites/ default/files/Major\%20Item \%20wise \%20 Import-2016.pdf.

Krishnamoorthy B, Gopalam A \& Abraham J 1988 Quality parameters of cinnamon (Cinnamomum verum) in relation to flush colour. Indian Cocoa Arec. Spices J. 12: 38.

Parthasarathy V A, Srinivasan V \& Prasath D 2009 Status and strategies of spices cultivation in island ecosystem. In: Souvenir and abstract book, National workshop cum seminar on status and future strategies of horticulture development in A \& N Islands held on 23$25^{\text {th }}$ January, 2009, CARI, pp.24-35.

Ranaware V S, Nawale R N, Khandekar R G \& Magdum M B 1995 Effect of season on air layering of cinnamon. Indian Cocoa Arec. Spices J. 19: 81-84.

Rema J, Krishnamoorthy B \& Mathew P A 1997 Vegetative propagation of major tree spicesa review. J. Spices Arom. Crops 6: 87-105.

Singh D R \& Sankaran M 2012 Problems and prospects of cultivation of spices and plantation crops in Andaman and Nicobar Islands. In: Souvenir cum abstract book, National Seminar on Technologies for improving productivity of spices and plantation crops. February 27-28, 2012, CARI, Port Blair, 81p.

Waman A A, Bohra P, Avinash N, Gautam R K \& Dam Roy S 2016 Air layering in cinnamon (Cinnamomum verum) in the context of Andaman and Nicobar Islands. Extension Folder, ICAR-Central Island Agricultural Research Institute, Port Blair, pp.1-6. 


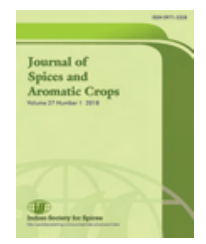

Stability analysis for seed yield and yield attributing traits in fennel (Foeniculum vulguare Mill.)

\author{
S L Sawargaonkar*, A K Singh \& S Sahu \\ College of Agriculture E Research Station, Indira Gandhi Krishi Vishwavidyalaya, \\ Raigarh-496 001, Chhattisgarh. \\ *E-mail: shrikant.sawargaonkar@gmail.com
}

Received 03 October 2018; Revised 30 April 2018; Accepted 02 May 2018

\begin{abstract}
Study was carried to evaluate phenotypic stability of 13 genotypes of fennel for seed yield and yield attributing traits. Out of 13 genotypes, three were checks (RF 205, RF 201 and local fennel) grown in Randomized Block Design (RBD) with three replications in each year. The significant genotypic differences were observed for all the characters suggesting differential responses of genotypes to the environmental changes. The results showed that among 13 genotypes RF 205 and Local fennel were found stable for seed yield plant ${ }^{-1}$, FNL 69 for days to flower, FNL 70 and RF 101 for primary branches plant ${ }^{-1}$, FNL 74 for umbels umbellet ${ }^{-1}$ and FNL 71 for umbels plant ${ }^{-1}$. The results revealed that some reliable predictions about $G \times E$ interaction as well as its unpredictable components contributed significantly in determining the stability of genotypes. The wider stability recorded by RF 205, RF 201 and local fennel during all the three years which will be useful for development of high yielding varieties of fennel.
\end{abstract}

Keywords: fennel, Foeniculum vulguare mill., stability, superiority

Fennel (Foeniculum vulguare mill.) is a highly cross pollinated and very important seed spice crop exhibiting $82.2 \%$ to $91.4 \%$ natural out crossing (Ramanujam et al. 1964). The hybridization of diverse genotypes followed by selection in segregating crop will be helpful in identifying heterozygous and heterogenous progeny. Insects plays an important role in maintaining heterogeneity in fennel crop. The existing varieties were developed using mass selection. Fennel seeds are having medicinal importance as carminative, cardiotonic, stimulant, vermicide and lactagogue (Lal 2014). The research efforts were for enhancing the productivity through developing high yielding inbreds and pure line varieties. India is the largest producer, consumer and exporter of spices and spice products. The total production of spices during 2013-14 was 5.9 MT from an area of 3.16 million ha (Annual Report 201415). Fennel had very little share to total production of spices. This yield gap can be minimized by growing suitable cultivars with appropriate packages of practices. For this development of high yielding and insect and pest resistant with good quality stable variety is essential. The newly variety must perform consistent performance across the 
environments and over the years for high yield and other yield attributing and quality traits. Phenotypically stable genotypes are of great importance because environmental conditions vary from season to season. Wider adaptation to a particular environment and consistent performance of recommended genotypes is one of the main objectives in breeding programme. A differential response of fennel genotypes when grown under different environments in the Rabi season has been reported by few scientists (Lal 2014; Drazic et al. 2014). Hence information on availability of stable high yielding varieties of Fennel is lacking. Keeping this in view, the present investigation was undertaken to determine the genotype $x$ environment (year) interaction on stability parameters and to identify the stable and responsive genotypes for yield and yield contributing characters of fennel for Chhattisgarh.

The experimental materials consisted of 13 genotypes obtained from All India Coordinated Research Project (AICRP) on spices, Indian Institute of Spices Research (IISR), Kozhikode, Kerala, evaluated for stability of seed yield and yield attributing traits for the three years during 2012-13 to 2014-15 at the experimental farm of College of Agriculture and Research Station (CARS), Raigarh $\left(21.9^{\circ} \mathrm{N}, 83.4^{\circ} \mathrm{E}, 215\right.$ $\mathrm{m})$, Indira Gandhi Krishi Vishwavidyalaya (IGKV), Chhattisgarh. Out of 13 genotypes RF 205, RF 201 and local fennel were standard checks grown in Randomized Block Design (RBD) with three replications. Twenty plants in each row in plot size of $4 \times 2.5 \mathrm{~m}$, were maintained after thinning. The inter- and intrarow spacing was kept at $45 \mathrm{~cm}$ and $20 \mathrm{~cm}$, respectively. The recommended package of cultural practices was followed to raise a good crop. In each plot, five competitive plants were identified randomly for recording data on days to $50 \%$ flowering, plant height $(\mathrm{cm})$, primary branches plant $^{-1}$, umbels plant ${ }^{-1}$, umblets umbel ${ }^{-1}$ and seed yield plot $^{-1}(\mathrm{~kg})$. The data recorded during three years were subjected to stability analysis according to the model proposed by Eberhart \& Russel (1966) and three stability parameters mean (m), regression coefficient (bi) and the deviation from linearity $\left(S^{2}\right.$ di) were estimated.

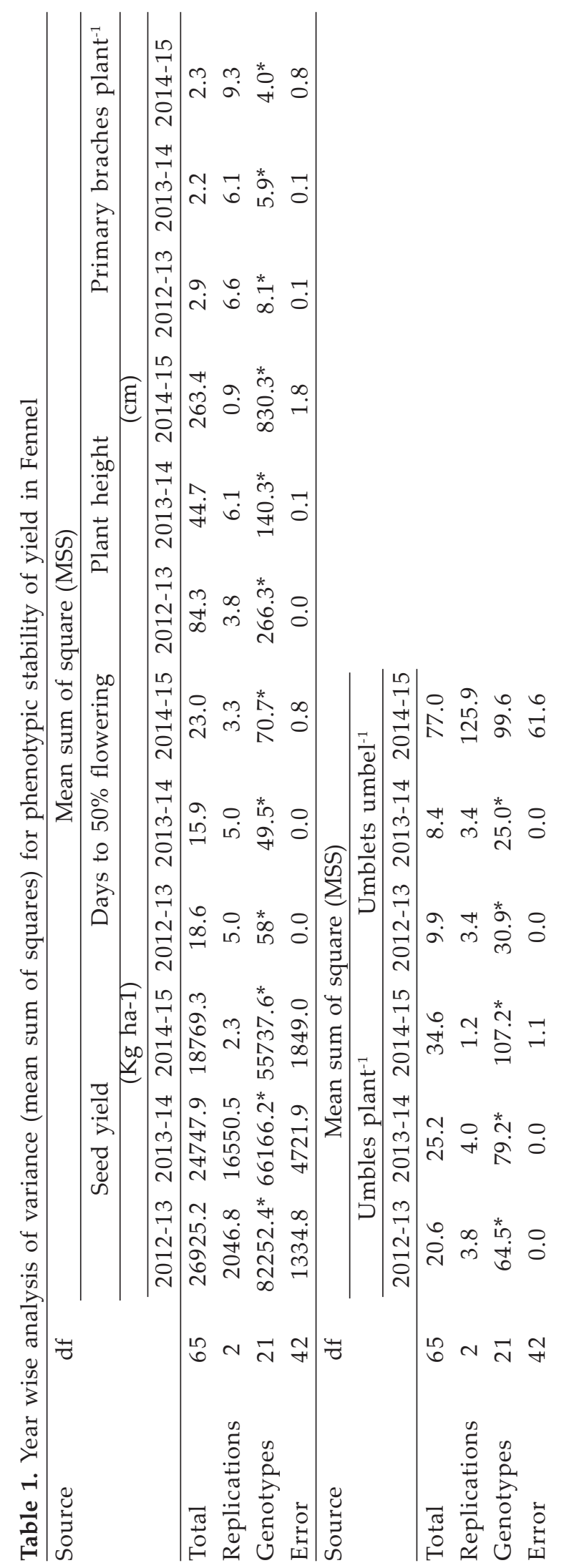


The genotypic differences were found to be highly significant for all the traits in each environment (year). The mean genotypic values from different year were subjected to pooled analysis. The mean sum of squares (MSS) due to genotypes $(\mathrm{G})$ and environments (E) were significant for all the traits except for primary branches plant ${ }^{-1}$ when tested against MSS due to genotype $x$ environments. It revealed the non significant differential response of the varieties to the changing environments. The results were in close conformity to the findings of Lal (2008), Verma \& Solanki (2015). The MSS due to $G \times E$ when tested against pooled error, were found highly significant for all the characters. Thus stability analysis was carried out for all the traits. The variance due to $\mathrm{G} \times \mathrm{E}$ were divided in to $G \times E$ (Linear) and due to pooled deviation (Non-linear). The $\mathrm{G} \times \mathrm{E}$ (Linear) mean squares were found significant for all the traits except primary branches plant $^{-1}$ indicating the presence of predictable components where as significance of pooled deviation for seed yield plot ${ }^{-1}$, days to $50 \%$ flowering, plant height $(\mathrm{cm})$, primary branches plant $^{-1}$ and umbels plant ${ }^{-1}$ showed the presence of non-predictable components. These observations indicated that some reliable predictions about $G \times E$ interaction as well as its unpredictable components can be made for these traits. Hence, both components contributed significantly in determining the stability of genotypes (Lal 2008; Verma \&
Solanki 2015). Among 13 genotypes RF 205 and Local fennel were found stable for seed yield plant $^{-1}$, FNL 69 for days to flower, FNL 70 and RF 101 for primary branches plant ${ }^{-1}$, FNL 74 for umbels umbel ${ }^{-1}$ and FNL 71 for umbels plant $^{-1}$ (Table 2).

For days to flower, umbelets /umbel and umbels plant $^{-1}$ FNL 69 had recorded wider stability (above average mean, bi $=1$ and $S^{2} d i=0$ ). The genotype FNL 70 was stable for plant height, primary branches plant ${ }^{-1}$, umbelets umbel ${ }^{-1}$ and umbels plant ${ }^{-1}$ but had low seed yield, indicating its adaptation to stress environments (Lal 2008) while genotype FNL 71 recorded stability for plant height and umbels plant ${ }^{-1}$. For umbels umbel ${ }^{-1}$ FNL 72 had high stability across the environments of Raigarh. The genotypes FNL 69, FNL 70 and FNL 71 were among the top entries which had their mean umbels plant ${ }^{-1}$ greater than the average of all the genotypes with regression coefficient (bi $=1$ ) and non-significant deviation for regression $\left(\mathrm{S}^{2} \mathrm{di}=0\right)$. This indicated their high stability over the different environments of years (Lal 2008). The genotype FNL 68 and RF 101 had above average mean for umbels plant ${ }^{-1}, S^{2} \mathrm{di}=0$ but the value of bi \#1, indicating their adaptation to high input conditions. For umbels plant ${ }^{-1}$ genotype RF 205 and FNL 67 had bi = 1 and $\mathrm{S}^{2} \mathrm{di}=0$, but their mean was low, indicating their adaptation to stress environments (Table $3)$.

Table 2. Analysis of variance (mean squares) for phenotypic stability of yield and yield contributing characters in Fennel

\begin{tabular}{|c|c|c|c|c|c|c|c|}
\hline \multirow[t]{2}{*}{ Source } & \multirow[t]{2}{*}{$\mathrm{df}$} & \multicolumn{6}{|c|}{ Mean square } \\
\hline & & $\begin{array}{l}\text { Seed yield } \\
\left(\mathrm{kg} \mathrm{ha}^{-1}\right)\end{array}$ & $\begin{array}{l}\text { Days to } \\
50 \% \text { flow }\end{array}$ & $\begin{array}{l}\text { Plant } \\
\text { height }\end{array}$ & $\begin{array}{l}\text { Prim. } \\
\text { Branch }\end{array}$ & $\begin{array}{l}\text { Umbels }^{-1} \\
\text { plant }\end{array}$ & $\begin{array}{l}\text { Umblets } \\
\text { umbel }^{-1}\end{array}$ \\
\hline Total & 38 & 48198.2 & 71.8 & 194.5 & 2.0 & 34.0 & $48.5^{* *}$ \\
\hline Genotypes & 12 & $49045.9^{*}$ & $25.4^{*}$ & $273.9^{* *}$ & 3.2 & $35.4^{* *}$ & $21.4^{* *}$ \\
\hline ENV & 2 & $507452.1^{*}$ & $1008.4^{* *}$ & $1221.2^{* *}$ & 1.7 & $145.1^{* *}$ & $21.4^{* *}$ \\
\hline $\begin{array}{l}\text { Environment } \\
(\text { Gen } \times \text { Env) } \\
\text { Environment }\end{array}$ & 26 & $47806.9^{*}$ & $25 .^{* *}$ & $157.8^{* *}$ & 1.4 & $33.4^{* *}$ & $61.1^{* *}$ \\
\hline $\begin{array}{l}\text { Linear } \\
\text { Gen. × Env }\end{array}$ & 1 & $1014905.6^{*}$ & $17^{* *}$ & $2442.0^{* *}$ & 3.4 & $290.3^{* *}$ & $1218.5^{* *}$ \\
\hline Linear & 12 & $17107.5^{*}$ & $25.1^{* *}$ & $122.7^{* *}$ & 0.3 & $44.7^{* * *}$ & $30.3^{* *}$ \\
\hline Pooled Deviation & 13 & $1752.6^{*}$ & $8.2^{*}$ & $14.5^{* *}$ & $2.3^{* *}$ & $3.2^{* *}$ & 0.1 \\
\hline Pooled error & 13 & 878.4 & 8.2 & 0.2 & 0.1 & 0.1 & 6.8 \\
\hline
\end{tabular}




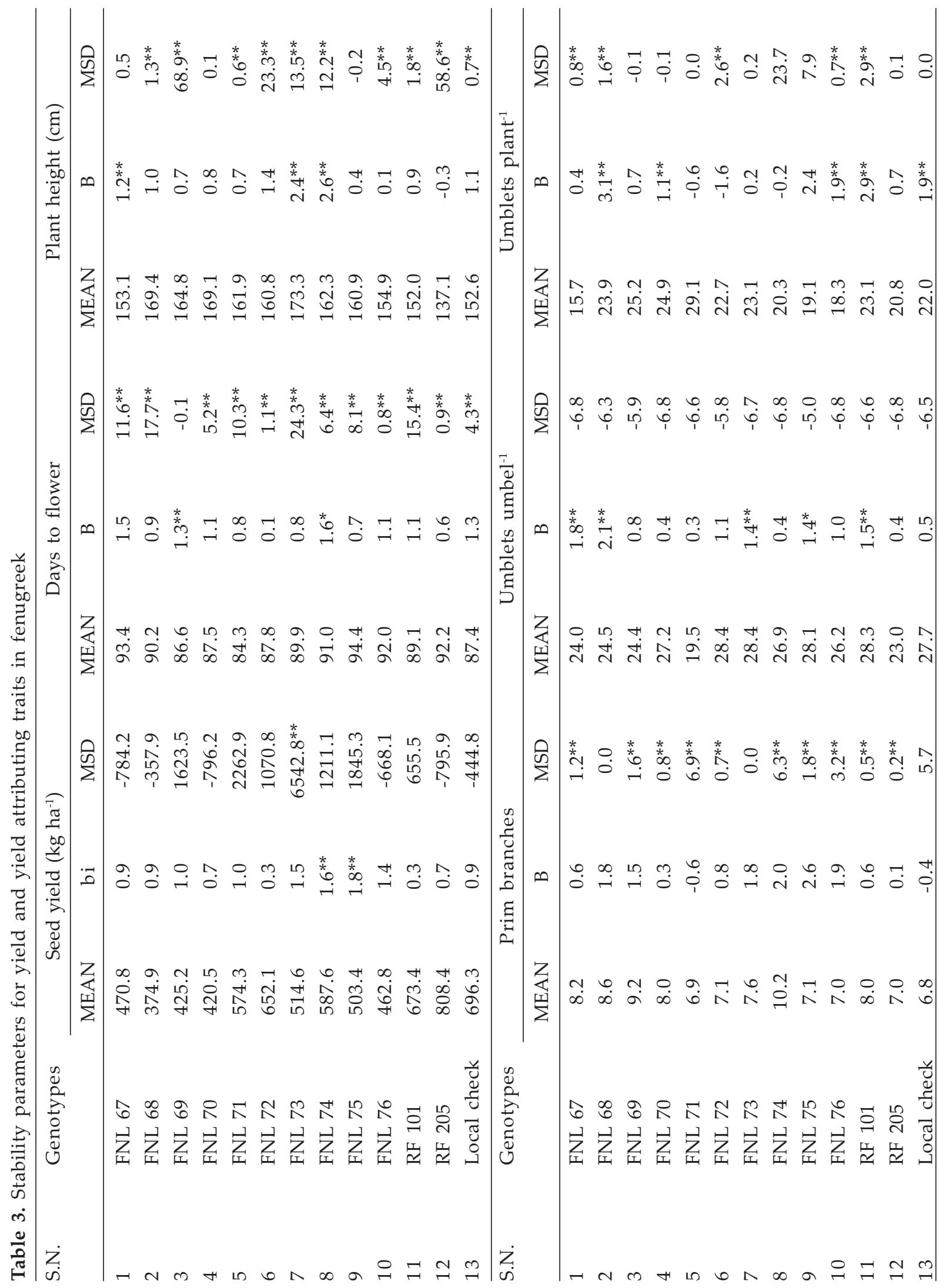


Table 4. Two way table showing stable and unstable genotypes for seed yield verses component characters

\begin{tabular}{|c|c|c|c|c|c|c|}
\hline \multirow{2}{*}{$\begin{array}{l}\text { Genotype } \\
\text { no }\end{array}$} & \multirow{2}{*}{$\begin{array}{l}\text { Stable } \\
\text { genotypes }\end{array}$} & \multicolumn{4}{|c|}{ Stability parameters (bi/S2di) of yield components } & \multirow[b]{2}{*}{$\begin{array}{l}\text { Umblets } \\
\text { umbel }^{-1}\end{array}$} \\
\hline & & $\begin{array}{l}\text { Days to } \\
\text { flower }\end{array}$ & $\begin{array}{l}\text { Plant } \\
\text { height }\end{array}$ & $\begin{array}{c}\text { Primary } \\
\text { bran plant }\end{array}$ & $\begin{array}{l}\text { Umbels } \\
\text { plant }^{-1}\end{array}$ & \\
\hline 12 & RF 205 (C) & S/S & $S / *$ & $\mathrm{~S} / \mathrm{S}$ & $\mathrm{S} / \mathrm{S}$ & S/S \\
\hline 13 & Local fennel (C) & $S / *$ & $S / S$ & $S / *$ & $\mathrm{~S} / \mathrm{S}$ & S/S \\
\hline
\end{tabular}

Where, $\mathrm{S}=$ stable genotypes; $\mathrm{S} / *, * / \mathrm{S}$ and ${ }^{*} / *$ unstable genotype; bi=regression coefficient; S2di=deviation from regression line; ${ }^{*}$ bi $\# 1$, S2di \#0

Based on stability parameters genotypes RF 205 and Local fennel were classified as stable for seed yield plant ${ }^{-1}$, which had their mean seed yield greater than the average of all the genotypes with unit regression coefficient (bi $=1$ ) and non-significant deviation from regression $\left(\mathrm{S}^{2} \mathrm{di}=0\right)$. This indicated their high stability over all the environments during 201213 to 2014-15. Lal (2008) and Verma \& Solanki

(2015) reported above average stability of Fennel genotypes for seed yield. The genotypes RF 101, FNL 72 and FNL 71 had above average mean, seed yield, regression coefficient of bi $=1$ but non-significant deviation from regression line $\left(S^{2} \mathrm{di}=0\right)$. Hence, indicating its specific adaptability under good agronomic management practices.

Table 5. Superiority of fennel genotypes for yield over checks during 2012-13 to 2014-15

\begin{tabular}{|c|c|c|c|c|c|}
\hline \multirow{3}{*}{ E.N. } & \multirow{3}{*}{ E.name } & \multicolumn{3}{|c|}{$2012-13$} & \\
\hline & & Yield $\left(\mathrm{kg} \mathrm{ha}^{-1}\right)$ & $\%$ superiority & Disease reaction & \\
\hline & & & RF 101(NC) & Local check & \\
\hline 6 & FNL 67 & 578.1 & $\mathrm{NO}$ & 2.75 & MR \\
\hline 11 & RF 101 (c) & 599.7 & $\mathrm{NO}$ & & MR \\
\hline 12 & RF205 (c) & 690.2 & $\mathrm{NO}$ & & MR \\
\hline \multirow[t]{2}{*}{13} & FNL (LC) & 562.6 & $\mathrm{NO}$ & & MR \\
\hline & & & $2013-14$ & & \\
\hline 6 & FNL 67 & & $\mathrm{NO}$ & 6.36 & MR \\
\hline 11 & RF 101 (c) & 686.9 & $\mathrm{NO}$ & & MR \\
\hline 12 & RF205 (c) & 777.1 & $\mathrm{NO}$ & & MR \\
\hline \multirow[t]{2}{*}{13} & FNL (LC) & 630.3 & $\mathrm{NO}$ & & MR \\
\hline & & & 2014-15 & & \\
\hline 1 & FNL 74 & 918.4 & 25.2 & 2.5 & MR \\
\hline 4 & FNL 75 & 914.9 & 24.7 & 2.1 & MR \\
\hline 20 & FNL 73 & 872.0 & 18.9 & -2.7 & MR \\
\hline 3 & FNL 71 & 807.3 & 10.0 & -9.9 & MR \\
\hline \multirow[t]{4}{*}{4} & FNL 76 & 770.4 & 5.0 & -14.0 & \\
\hline & RF 205 & 957.9 & 30.6 & 6.9 & \\
\hline & Local check & 896.2 & 22.2 & 0.0 & \\
\hline & RF 101 & 733.6 & 0.0 & & \\
\hline
\end{tabular}

Where, No=No superiority; NC=National check 
For the present study the meterological parameters recorded with Indian meterological standard week of 31 for first week of sowing, 37 for vegetative stage, 43 for flowering stage and 49 for physiological maturity stage respectively for 2012-13 to 2014-15 (Table 6). It was observed that during sowing period average optimum temperature of $27.6^{\circ} \mathrm{C}+$ $21.2^{\circ} \mathrm{C}$ were present over all the three years. At the same time average maximum humidity of $88.2 \%$ with minimum of $66.9 \%$ were recorded during first week of sowing. During vegetative stage of fennel crop mean maximum temperature of $24.9^{\circ} \mathrm{C}$ and minimum temperature of $15.2^{\circ} \mathrm{C}$ with humidity range of
$87.2 \%$ to $60.7 \%$ recorded. At flowering time consistent maximum minimum temperature of $24.9^{\circ} \mathrm{C}-15.2^{\circ} \mathrm{C}$ respectively registered with average humidiy of $89.2 \%$ to $38.4 \%$ present. At physiological maturity mean maximumminimum temperature of $32.0^{\circ} \mathrm{C}-15.0^{\circ} \mathrm{C}$ were registered while maximum humidity of $81.8 \%$ and minimum temperature of $37.3 \%$ were recorded. It was observed that at all the three years no rainfall during throughout the crop period.

The genotype FNL 67 had recorded 2.75 and 6.36 percent superiority for seed yield over local check during 2012-13 and 2013-14 respectively.

Table 6. Meterological parameters during crop growth period from 2012-13 to 2014-15

\begin{tabular}{|c|c|c|c|c|c|}
\hline \multirow[t]{3}{*}{ Year } & & \multirow{2}{*}{$\begin{array}{c}\text { Temperature } \\
\left({ }^{\circ} \mathrm{C}\right)\end{array}$} & \multicolumn{2}{|c|}{ Humidity } & \multirow{3}{*}{$\begin{array}{l}\text { Rain } \\
\text { fall } \\
(\mathrm{MM})\end{array}$} \\
\hline & \multirow[b]{2}{*}{ Max } & & \multicolumn{2}{|c|}{$(\%)$} & \\
\hline & & Min & Max & Min & \\
\hline & & \multicolumn{3}{|c|}{ Seed germination week } & \\
\hline $2012-13$ & 27.85 & 18.57 & 90.71 & 61.14 & Nil \\
\hline 2013-14 & 27.86 & 23.86 & 86 & 71.28 & Nil \\
\hline 2014-15 & 27 & 21.28 & 88 & 68.14 & Nil \\
\hline \multirow[t]{2}{*}{ Average } & 27.6 & 21.2 & 88.2 & 66.9 & \\
\hline & & \multicolumn{3}{|c|}{ Vegetative stage } & \\
\hline $2012-13$ & 25.14 & 16.28 & 90.71 & 64.14 & Nil \\
\hline 2013-14 & 24.29 & 13 & 80.28 & 53.71 & Nil \\
\hline 2014-15 & 25.14 & 16.25 & 90.71 & 64.14 & Nil \\
\hline \multirow[t]{2}{*}{ Average } & 24.9 & 15.2 & 87.2 & 60.7 & \\
\hline & & \multicolumn{3}{|c|}{ Flowering stage } & \\
\hline $2012-13$ & 25.42 & 11.42 & 88.71 & 29 & Nil \\
\hline 2013-14 & 25.71 & 15.42 & 89.57 & 57.28 & Nil \\
\hline 2014-15 & 25.42 & 11.42 & 88.71 & 29 & Nil \\
\hline \multirow[t]{2}{*}{ Average } & 25.5 & 12.8 & 89.0 & 38.4 & \\
\hline & & \multicolumn{3}{|c|}{ Physiological maturity } & \\
\hline $2012-13$ & 32.71 & 14.71 & 83 & 32.71 & Nil \\
\hline 2013-14 & 26.14 & 13.43 & 81.57 & 55.14 & Nil \\
\hline 2014-15 & 37.14 & 16.71 & 80.71 & 24 & Nil \\
\hline Average & 32.0 & 15.0 & 81.8 & 37.3 & \\
\hline
\end{tabular}


During 2014-15 five genotypes FNL 74, FNL 75, FNL 73, FNL 71, and FNL 76 recorded high heterosis for seed yield over RF 205 and RF 101, whereas FNL 74 \& FNL 75 registered positive heterosis over local check.

It was observed that national check (RF 205) showed wider stability for seed yield, days to flower, primary branches plant ${ }^{-1}$, umbels plant $^{-1}$ and umbelets umbel ${ }^{-1}$ while local fennel had wider stability for seed yield $\left(\mathrm{kg} \mathrm{ha}^{-1}\right)$, plant height, umbels plant ${ }^{-1}$ and umbelets umbel ${ }^{-1}$. While none of the test entries showed superior stable performance over the national and local checks during all the three years. This appears to be evidence for much greater genotype $x$ environment interaction for the entries to be evaluated than for the pure lines. This is somewhat unexpected in view of the greater homeostasis in unfavorable environments usually found in heterozygous genotypes. This needs further study.

\section{Acknowledgements}

Authors are thankful to Project Coordinator of AICRP on Spies, Kozhikode for support and constant encouragement. Authors are also thankful to Directorate of Research, Indira Gandhi Krishi Vishwavidyalaya (IGKV) for providing facility for conducting trial successfully.

\section{References}

Annual Report 2014 Department of Agriculture And Cooperation, Ministry of Agriculture Government of India, Krishi Bhawan, New Delhi, March, 2015 pp.28-29.

Eberhart SA \& Russell WA 1966 Stability parameters for comparing varieties. Crop Sci. 2: 357-361.

Lal RK 2008 Stability and genotype $\mathrm{x}$ environment interaction in Fennel. J. Herbs, Spices Med. Plants 13: 47-54.

Ramanujam S, Joshi BS, \& Saxena M B L 1964 Extent and randomness of cross-pollination in some umbelliferous spices of India. Indian J. Gen. 24: 62-67.

Ramanujam S \& Tewari V P 1970 Heterosis breeding in Fennel. Indian J. Gen. Plant Br. 30: 732-737.

Venkateswarlu O 1998 Phenotypic stability for grain yield in pigeonpea. Int. J. Chickpea Pigeonpea Newslett. 5: 41-42.

Lal R K 2014 Stability and genotype × environment Interaction in fennel. J. Herbs Spices Med. Plants 13: 47-54.

Verma P \& Solanki RK 2015 Stability of seed yield and its component traits in fennel Foeniculum vulgare). Indian J. Agril. Sci. 85: 1504-1507.

Drazic S, Zinanovic T \& Prodanovic S 2014 Stability of productive traits of genotypes of cultivated medicinal plants of family Apiaceae. Biotechnol. Biotechnol. Equipments 21: 100-106. 
Effect of irrigation methods and mulching on growth and yield parameters of chilli (Capsicum annum L.) in arid condition

\author{
R L Bhardwaj ${ }^{1}$, M M Sundria, S R Kumhar \& N Kumar \\ Agricultural Research Station, Agriculture University, Jodhpur-342 304, Rajasthan. \\ *E-mail: rajubhardwaj3@gmail.com
}

Received 20 May 2017; Revised 25 February 2018; Accepted 26 March 2018

\begin{abstract}
The research work was carried out to study the impact of various irrigation methods and mulching on plant growth, production and profitability of chilli cv. R.Ch. 1 at Agricultural Research Station, Mandor, Jodhpur during July, 2016 to February, 2017. The results of surface irrigation were compared with drip irrigation system under no mulch and in conjunction with plastic mulch. The results revealed that the crop was irrigated by drip irrigation on raise bed with 100 micron Linear Low Density Poly Ethylene plastic mulch ( $\mathrm{T}_{8}$ treatment) exhibited significantly higher seedling survival at 15 and 30 days after transplanting (95.16\% and 91.70\%), highest plant height $\left(47.10 \mathrm{~cm}\right.$ at 45 DAT and $54.60 \mathrm{~cm}$ at harvest), highest number of branches (14.93) plant ${ }^{-1}$, maximum stem girth $(2.32 \mathrm{~cm})$ number of roots plant ${ }^{-1}(138.5)$, highest fruit set $(38.47 \%)$, length of fresh fruit $(12.56 \mathrm{~cm})$, diameter of fruit $(3.52 \mathrm{~cm})$ and fresh weight of fruit ${ }^{-1}(8.42 \mathrm{~g})$ was observed. The maximum number of fruits plant ${ }^{-1}(125)$, highest yield plant ${ }^{-1}(1052.5 \mathrm{~g})$, yield ha ${ }^{-1}(337.63 q)$ and premier fruit quality score (9.11) with maximum net return (Rs.326407.28) and benefit: cost ratio (3.41) was also reported in same treatment. Comparatively minimum time (15 hours) required for one hectare irrigation was also reported in drip irrigation on raise bed with plastic mulch.

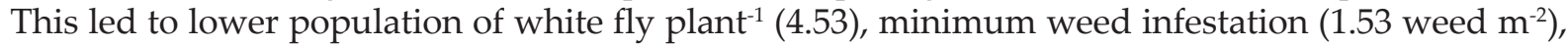
leaf curl $(5.50 \%)$ and fruit rot $(5.0 \%)$ incidence than other treatment combinations. The minimum growth, yield and profitability were reported in check basin method of irrigation without mulch ( $\mathrm{T}_{1}$ treatment).
\end{abstract}

Keywords: Capsicum annum, Day After Transplanting, leaf curl, surface irrigation, survival

Chilli (Capsicum annuum L.) is an important commercial vegetable cum spice crop of India belongs to the family Solanaceae. The production of chilli crop is affected adversely by moisture deficit. Productivity of the crop can be increased by adopting improved package of practices, particularly in-situ moisture conservation by mulching as well as high-tech irrigation especially drip irrigation with appropriate irrigation scheduling. Use of soil cover and mulching is also known to be beneficial chiefly through their influence on soil moisture conservation, solarization and control of weeds. Beneficial response of plants 
to mulch includes early production, more yield and reduced insect and disease problems (Pattanaik et al. 2003). Linear Low Density Poly Ethylene (LLDPE) plastic films have been proved as better mulch because of their puncture resistance quality, thinness and lower cost (Panda 2004). Numerous experiments have reported the benefits of LLDPE mulch in several crops, but research is limited on response of chilli production in western Rajasthan by this method. Keeping this in background, the present study was undertaken to study the effect of different irrigation methods and mulching on chilli crop and compare the result with the conventional method of growing the crop under surface irrigation without mulch.

A field experiment was conducted at Agricultural Research Station, Mandor, Jodhpur (Rajasthan), India during kharif seasons of year 2016-17. The soil of experimental plot was of sandy loam texture with average $\mathrm{pH}$ range 8.5 , having organic carbon $0.55 \%$, available N $180 \mathrm{~kg} \mathrm{ha}^{-1}$, P $27.5 \mathrm{~kg} \mathrm{ha}^{-1}$ and $\mathrm{K}$ $250.0 \mathrm{~kg} \mathrm{ha}^{-1}$ during experimentation. The experiment was conducted in a completely randomized design having nine treatments comprising by different irrigation methods and mulching viz., $\mathrm{T}_{1}=$ Check basin method, $\mathrm{T}_{2}=$ furrow irrigation method, $\mathrm{T}_{3}=$ Raise bed with trench method, $\mathrm{T}_{4}=$ Flat bed with drip irrigation, $\mathrm{T}_{5}=$ Flat bed + plastic mulch + drip irrigation, $\mathrm{T}_{6}=$ Raise bed with drip irrigation, $\mathrm{T}_{7}=$ Raise bed + organic mulch + drip irrigation, $\mathrm{T}_{8}=$ Raise bed + plastic mulch + drip irrigation, $\mathrm{T}_{9}=$ Sprinkler irrigation method. In well prepared field, transplanting of Chilli seedlings variety RCh 1 of 35-40 days old were planted in pair row method with a spacing of $45 \mathrm{~cm} x$ $45 \mathrm{~cm} / 90 \mathrm{~cm}\left(33,333\right.$ plant ha $\left.{ }^{-1}\right)$ during last week of June. In check basin and sprinkler system of irrigation the bed size is $2 \times 2$ meter and in all other methods is $1 \times 4$ meters. The cultural practices of the crop were followed as per the recommendations. The organic material and LLDPE silver colour film of 100-micron thickness was used for mulching around the plant. The lateral lines of $12 \mathrm{~mm}$ diameter LLDPE pipes were laid along with crop rows.
The laterals were provided with inlet drippers of 8 litre $\mathrm{hr}^{-1}$ discharge capacity. All the observations were taken from five randomly selected plant of each replication throughout the investigation period at appropriate time by adopting standard method for growth, development, fruiting behavior and yield.

Seedling survival per cent (after transplanting in main field at 15 DAT and 30 DAT) was recorded by following formula;

Survival percent $=[$ Total survival transplanted plants / Total transplanted plants] $\times 100$

Plant height (at 45 DAT and at harvesting) was measured from soil surface upto the highest shoot tip by straightening all branches. Stem girth was measured $1 \mathrm{~cm}$ from the base of the stem using vernier calliper. Observation of number of branches, days taken to first flower initiation, duration of fruiting period and number of fruit plant ${ }^{-1}$ was recorded by standard counting method. Number of roots, root length was measured by destructive method of uprooting the plants and taking measurement by standard method. Length of fresh fruits measured by scale and fruit diameter using vernier calliper and expressed in centimeter. Fruit set per cent was recorded by following formula;

Fruit set per cent $=[$ Total number of fruit set plant $^{-1} /$ Total number of flowers plant $\left.{ }^{-1}\right] \times 100$

Fruit weight was determined by weighing method at the time of harvesting and expressed in gram fruit ${ }^{-1}$. The total fruit yield plant ${ }^{-1}$ and hectare $^{-1}$ was calculated by weighing total marketable fruits and has been expressed in gram and quiantal respectively. Further, the net return was calculated by subtracting cost of each treatment from gross return. The gross return was calculated from yield multiplied by average market rate during the period of investigation. The benefit cost ratio was calculated by dividing net return to total cost of cultivation. Benefit-Cost ratio and net profit were carried out to determine the economic feasibility of the crop using surface and drip irrigation as suggested by Tiwari et al. (1998a). 
The seasonal system cost of drip irrigation system included depreciation, prevailing bank interest rate, and repair and maintenance cost of the system. The fixed cost of drip irrigation system was determined to be Rs 112,000 ha-1. The useful life of drip system was considered to be 10 years. The system cost was evaluated by distributing the fixed cost of system over life period of drip irrigation set. For calculating depreciation, the life of the drip irrigation set and $10 \%$ junk value was considered. The interest was calculated on the average of investment of the drip irrigation set taking into consideration the value of the set in the first and last year @10\% per annum. Cost of repairs and maintenance of set is @2\% of initial cost of the drip irrigation set per year. The cost of cultivation includes expenses incurred in land preparation, interculture operation, fertilizer, crop protection measures, irrigation water and harvesting with labour charges. Therefore, total seasonal cost was worked as: depreciation, interest, repairs and maintenance cost of set + cost of cultivation + cost of mulch. The income from produce was calculated using prevailing average market price of capsicum @ Rs $1250 \mathrm{q}^{-1}$. Disease incidence (leaf curl and fruit rot) and quality of fruits was measured by visual inspection (Five member team of crop experts and plant pathologist). White fly population plant $^{-1}$ and weed infestation meter ${ }^{-2}$ was calculate by simple counting method. The time required for irrigation was calculated as per actual required time of irrigation of specified area by different methods of irrigation. To test the significance of variance of data obtained from crop growth, yield and economics of variance technique for completely randomized design was done by standard procedure prescribed by Panse \& Sukhatme (1985). Significance of difference among the treatments effect was tested by ' $\mathrm{F}$ ' test and critical difference (CD) was calculated, wherever the results were significant.

The results revealed that, the irrigation methods and mulching are significantly influenced growth attributes at all the growth stages (Table 1). The maximum seedling survival per cent at 15 DAT (95.10\%) and 30 DAT (91.70\%) was recorded in $\mathrm{T}_{8}$ treatment, which was significantly superior to other treatment but at par with $\mathrm{T}_{6}$, and $\mathrm{T}_{7}$ treatments. The maximum survival per cent of seedling in $\mathrm{T}_{8}$ treatment might be due to more favourable moisture condition for seedling transplanting and reestablishment of roots than others. The height of plant under treatment T8 $(47.10 \mathrm{~cm}$ at 45 DAT) and treatment T6 $(62.60 \mathrm{~cm}$ at harvest $)$ was found highest among all other treatments and is $67.19 \%$ and $13.40 \%$ higher than the $\mathrm{T}_{1}$ treatment. About to number of branch plant ${ }^{-1}$, maximum value was recorded in treatment T8 (14.93) followed by treatment T7 (12.53) and the lowest value was in treatment T1 (7.17). Maximum stem girth at harvest $(2.36 \mathrm{~cm})$ and highest number of roots plant ${ }^{-1}$ (138.50) were observed in $\mathrm{T}_{8}$ treatment whereas longest root system $(10.50 \mathrm{~cm})$ was observed in $\mathrm{T}_{3}$ treatment. The minimum stem girth $(1.68 \mathrm{~cm})$ and the number of roots plant ${ }^{-1}$ (53.57) were observed in $\mathrm{T}_{1}$ treatment whereas shortest root system $(7.97 \mathrm{~cm})$ was observed in $\mathrm{T}_{9}$ treatment. The higher available moisture status in soil favourably influences the uptake of nutrients which maintains the cell turgidity, cell elongation, photosynthesis and respiration at optimum level, leading to favourable growth and development of plant in terms of plant height, number of branches plant ${ }^{-1}$, stem girth and number of root plant $t^{-1}$ in the present study. The highest increase in vegetative growth in drip irrigation with mulching might be due to the availability of soil moisture as well as favourable temperature at optimum level for plant growth development (Pattanaik et al. 2003; Paul et. al. 2013). The lowest value of vegetative growth in $\mathrm{T} 1 \mathrm{might}$ be because of unfavourable moisture regime (moisture stress or excess moisture) in the soil through surface irrigation and competition of weeds for nutrients (Pattanaik et al. 2003; Agrawal \& Agrawal 2005). The increased growth attributes might have supplied water and nutrients in adequate proportion, which resulted in triggering the production of plant growth hormone, viz., indole acetic acid (IAA) and 
Table 1. Effect of different irrigation methods and mulching on vegetative parameter of chilli

\begin{tabular}{|c|c|c|c|c|c|c|c|c|}
\hline \multirow[t]{2}{*}{ Treatments } & \multicolumn{2}{|c|}{$\begin{array}{l}\text { Seedling } \\
\text { survival } \\
\%\end{array}$} & \multicolumn{2}{|c|}{$\begin{array}{l}\text { Plant } \\
\text { height } \\
(\mathrm{cm})\end{array}$} & \multirow{2}{*}{$\begin{array}{l}\text { Average } \\
\text { number of } \\
\text { branches } \\
\text { plant }^{-1}\end{array}$} & \multirow[t]{2}{*}{$\begin{array}{l}\text { Stem girth } \\
\text { at harvest } \\
(\mathrm{cm})\end{array}$} & \multirow[t]{2}{*}{$\begin{array}{l}\text { Length } \\
\text { of root } \\
(\mathrm{cm})\end{array}$} & \multirow[t]{2}{*}{$\begin{array}{l}\text { No. of } \\
\text { roots plant } \\
\text { plant }^{-1}\end{array}$} \\
\hline & 15 DAT & 30 DAT & $45 \mathrm{DAT}$ & $\begin{array}{c}\text { At } \\
\text { harvest }\end{array}$ & & & & \\
\hline $\mathrm{T}_{1}$ & 78.17 & 73.93 & 28.17 & 55.20 & 7.17 & 1.68 & 9.50 & 53.57 \\
\hline $\mathrm{T}_{2}$ & 82.37 & 79.23 & 29.07 & 57.30 & 8.07 & 1.86 & 10.00 & 69.77 \\
\hline $\mathrm{T}_{3}$ & 86.97 & 83.83 & 32.07 & 61.70 & 8.27 & 1.88 & 10.50 & 78.37 \\
\hline $\mathrm{T}_{4}$ & 88.40 & 84.73 & 34.03 & 61.55 & 9.48 & 2.26 & 8.53 & 102.50 \\
\hline $\mathrm{T}_{5}$ & 90.10 & 86.33 & 38.53 & 61.70 & 10.28 & 2.33 & 8.03 & 108.70 \\
\hline $\mathrm{T}_{6}$ & 92.50 & 89.33 & 40.43 & 62.60 & 9.98 & 2.32 & 9.03 & 119.00 \\
\hline $\mathrm{T}_{7}$ & 93.40 & 90.90 & 41.97 & 53.20 & 12.53 & 2.30 & 8.97 & 135.70 \\
\hline $\mathrm{T}_{8}$ & 95.10 & 91.70 & 47.10 & 54.60 & 14.93 & 2.36 & 8.47 & 138.50 \\
\hline $\mathrm{T}_{9}$ & 85.20 & 80.10 & 34.90 & 56.70 & 9.73 & 2.00 & 7.97 & 110.10 \\
\hline S.Em. + & 1.646 & 1.539 & 2.173 & 1.859 & 0.442 & 0.088 & 0.228 & 1.300 \\
\hline $\mathrm{CD}(\mathrm{P}<0.05)$ & 4.871 & 4.556 & 6.432 & 5.504 & 1.327 & 0.260 & 0.675 & 3.848 \\
\hline
\end{tabular}

higher number of leaves and roots throughout the cropping period (Sankar et al. 2008).

The drip irrigation in combination with mulch significantly increased the yield of chilli as compared to drip irrigation without mulch (Table 2) and surface irrigation methods. The minimum days (42.38) required for first flower initiation was reported in $\mathrm{T}_{9}$ treatment whereas the maximum days (51.39) was required in $\mathrm{T}_{5}$ treatment. Among various treatments, highest fruit set $(38.47 \%)$, length of fresh fruit $(12.56$ $\mathrm{cm})$, diameter of fruit $(3.52 \mathrm{~cm})$, duration of fruiting (71.38 days), fresh weight of fruit ${ }^{-1}$ (8.42 g), maximum number of fruits plant ${ }^{-1}(125)$, highest yield plant ${ }^{-1}(1052.5 \mathrm{~g})$ and yield ha-1 (337.63 q) was recorded under $\mathrm{T}_{8}$ treatment, whereas lowest yield (153.45 q ha $\left.{ }^{-1}\right)$ was recorded under $T_{1}$ treatment. This might be due to water stress during the critical growth period and fruit development stage coupled with aeration problem in first few days immediately after irrigation. Another reason to get low yield by surface irrigation without mulch might be due to less availability of nutrients for crop growth due to leaching and high weed competition between the crops (Pattanaik et al. 2003). In drip irrigation system on raise bed with plastic mulch the water is applied at a low rate for a longer period at frequent intervals near the plant root zone through lower pressure delivery system, which increases the availability of nutrients near the root zone with a reduction in leaching losses and minimum weed competition. More nutrient availability, especially near the root zone might have increased the translocation of photosynthetes to storage organ of chilli resulting in an increased weight of fruits. This result corroborated the findings of Singh (2007), Sankar et al. (2008), Paul et al. (2013) and Kumar et al. (2016).

Irrigation methods and mulching also significantly influenced the gross return, net return and benefit cost ratio in chill (Table 3). Maximum net profit of Rs. 326407.28 ha $^{-1}$ with $\mathrm{B}$ : C ratio of 3.41 was recorded in $\mathrm{T}_{8}$ treatment followed by Rs 296192.61 ha $^{-1}$ with B: C ratio of 3.11 in $\mathrm{T}_{5}$ treatment and lowest net profit of Rs 119007.80 ha $^{-1}$ with a B: C ratio of 1.63 in $T_{1}$ treatment (Table 3). It is observed that, the drip 
Table 2. Effect of different irrigation methods and mulching on yield and yield attributes of chilli

\begin{tabular}{lccccccccc}
\hline Treatments & $\begin{array}{c}\text { First } \\
\text { flower } \\
\text { initiation } \\
\text { (DAT) }\end{array}$ & $\begin{array}{c}\text { Fruit } \\
\text { set } \\
\%\end{array}$ & $\begin{array}{c}\text { Length } \\
\text { of fresh } \\
\text { fruit } \\
\text { (cm) }\end{array}$ & $\begin{array}{c}\text { DiameterDuration } \\
\text { of fresh } \\
\text { fruit } \\
\text { (cm) }\end{array}$ & $\begin{array}{c}\text { Weight } \\
\text { fruiting } \\
\text { (days) }\end{array}$ & $\begin{array}{c}\text { of single } \\
\text { fresh } \\
\text { fruit } \\
(\mathrm{gm})\end{array}$ & $\begin{array}{c}\text { No. of } \\
\text { fruits } \\
\text { plant }\end{array}$ & $\begin{array}{c}\text { Yield } \\
\text { plant }^{-1} \\
(\mathrm{gm})\end{array}$ & $\begin{array}{c}\text { Yield } \\
\text { ha }^{-1} \\
(\mathrm{q})\end{array}$ \\
\hline $\mathrm{T}_{1}$ & 45.70 & 17.23 & 10.75 & 2.87 & 52.70 & 7.63 & 60.33 & 460.34 & 153.45 \\
$\mathrm{~T}_{2}$ & 47.70 & 17.01 & 11.30 & 2.75 & 54.00 & 7.79 & 65.33 & 508.95 & 169.65 \\
$\mathrm{~T}_{3}$ & 47.40 & 21.31 & 11.35 & 2.78 & 56.10 & 7.82 & 68.33 & 534.37 & 178.12 \\
$\mathrm{~T}_{4}$ & 49.19 & 27.00 & 12.01 & 3.01 & 62.39 & 7.97 & 74.17 & 591.11 & 197.03 \\
$\mathrm{~T}_{5}$ & 51.39 & 31.81 & 12.19 & 3.14 & 68.59 & 8.23 & 114.17 & 939.59 & 313.19 \\
$\mathrm{~T}_{6}$ & 49.99 & 30.89 & 12.39 & 3.22 & 60.39 & 8.26 & 89.17 & 736.52 & 245.50 \\
$\mathrm{~T}_{7}$ & 46.58 & 36.74 & 12.30 & 3.28 & 66.38 & 8.36 & 95.00 & 794.20 & 251.53 \\
$\mathrm{~T}_{8}$ & 48.38 & 38.47 & 12.56 & 3.52 & 71.38 & 8.42 & 125.00 & 1052.50 & 337.63 \\
$\mathrm{~T}_{9}$ & 42.38 & 16.27 & 11.57 & 3.10 & 47.58 & 7.90 & 75.00 & 592.50 & 184.30 \\
$\mathrm{~S} . \mathrm{Em} .+$ & 1.247 & 1.570 & 0.201 & 0.059 & 1.247 & 0.133 & 1.302 & 9.913 & 8.257 \\
$\mathrm{CD}(\mathrm{P}<0.05)$ & 3.693 & 4.649 & 0.595 & 0.176 & 3.693 & 0.395 & 3.854 & 29.337 & 24.437 \\
\hline
\end{tabular}

irrigation with mulched treatments $\mathrm{T}_{5}, \mathrm{~T}_{7}$ and $\mathrm{T}_{8}$ gave better net return with higher $\mathrm{B}$ : $\mathrm{C}$ ratio $\mathrm{ha}^{-1}$ than their corresponding treatments without mulching in conventional irrigation method. The highest net return (US\$ $7098 \mathrm{ha}^{-1}$ ), incremental net return (US\$ $1556 \mathrm{ha}^{-1}$ ), and incremental benefit-cost ratio (7.03) were found for $50 \%$ water application with straw mulch (Biswas et al. 2015). The results are in conformity with the findings of Singh (2007), Sankar et al. (2008) and Kumar et al. (2016). Apart from reducing water consumption, drip irrigation with mulching also helps in reducing cost of cultivation and improving productivity of crops as compared to the same crops cultivated under flood method of irrigation (Paul et al. 2013).

Irrigation time significantly pretentious by different irrigation methods. The minimum time required in irrigation ( 14.50 hours) in $T_{5}$ treatment which closely followed by $\mathrm{T}_{8}$ treatment. Drip irrigation method with or without mulching required less irrigation time than without mulching in conventional irrigation method. There was significant effect of LLDPE mulch over drip irrigation system alone. Drip irrigation with LLDPE mulching $\left(\mathrm{T}_{5} \& \mathrm{~T}_{8}\right.$ treatment) saving irrigation time (21.40 hour ha ${ }^{-1}$ and 21.35 hour ha-1) upto 60 per cent by reducing water losses and increased irrigation efficiency. The increase in water saving per cent in trench method $\left(\mathrm{T}_{2}\right)$, drip irrigation system alone $\left(\mathrm{T}_{4}\right)$, drip irrigation system with LLDPE mulch $\left(\mathrm{T}_{5} \& \mathrm{~T}_{8}\right)$, drip irrigation with organic mulch $\left(\mathrm{T}_{7}\right)$ and sprinkler system $\left(\mathrm{T}_{q}\right)$ over conventional surface irrigation by check basin method $\left(\mathrm{T}_{1}\right)$ was $38.8 \%, 46.6 \%, 60.0 \%, 54.4 \%$ and $41.9 \%$ respectively. The highest water use efficiency of $592 \mathrm{~kg} \mathrm{ha}^{-1} \mathrm{~mm}^{-1}$ was obtained with 50 per cent water application under polyethylene mulch (Biswas et al. 2015). Drip irrigation with mulching helps to achieve yield gains of upto 100 per cent, water savings of upto $40-80$ per cent, and associated fertilizer, pesticide, and labour savings over conventional irrigation systems in capsicum crop (Paul et al. 2013). Similar trend has been reported in water use efficiency for okra crop by Tiwari et al. (1998a) and for tomato crop by Singh (2007). 
Table 3. Effect of different irrigation methods and mulching on economics, fruit quality, water saving $(\%)$, insect-pest and weed infestation of chilli

\begin{tabular}{lcccccccc}
\hline $\begin{array}{l}\text { Treat- } \\
\text { ments }\end{array}$ & $\begin{array}{c}\text { Net } \\
\text { Return }\end{array}$ & $\begin{array}{c}\text { B:C } \\
\text { ratio }\end{array}$ & $\begin{array}{c}\text { Quality } \\
\text { score of } \\
\text { fruits }\end{array}$ & $\begin{array}{c}\text { Water } \\
\text { saving (\%) } \\
\text { time (h) } \\
\text { for ha }{ }^{-1} \\
\text { irrigation }\end{array}$ & $\begin{array}{c}\text { No. of } \\
\text { white fly } \\
\text { plant }\end{array}$ & $\begin{array}{c}\text { Fruit } \\
\text { Rot } \\
(\%)\end{array}$ & $\begin{array}{c}\text { Leaf } \\
\text { curl } \\
(\%)\end{array}$ & $\begin{array}{c}\text { Weed } \\
\text { Infest- } \\
\text { ation }\end{array}$ \\
\hline $\mathrm{T}_{1}$ & 119007.80 & 1.63 & 7.24 & $36.30(0.0 \%)$ & 17.43 & 20.02 & 15.84 & 30.03 \\
$\mathrm{~T}_{2}$ & 135858.99 & 1.78 & 7.46 & $22.20(38.8 \%)$ & 13.73 & 18.02 & 12.34 & 17.43 \\
$\mathrm{~T}_{3}$ & 144550.55 & 1.85 & 8.04 & $22.45(38.2 \%)$ & 12.43 & 14.02 & 10.84 & 15.53 \\
$\mathrm{~T}_{4}$ & 170392.68 & 2.24 & 8.00 & $19.40(46.6 \%)$ & 11.60 & 10.82 & 9.50 & 12.40 \\
$\mathrm{~T}_{5}$ & 296192.61 & 3.11 & 8.50 & $14.50(60.0 \%)$ & 7.90 & 7.82 & 7.30 & 2.10 \\
$\mathrm{~T}_{6}$ & 225678.88 & 2.78 & 8.20 & $18.15(50.0 \%)$ & 10.40 & 8.82 & 8.60 & 10.10 \\
$\mathrm{~T}_{7}$ & 230913.36 & 2.77 & 8.50 & $16.55(54.4 \%)$ & 9.53 & 6.00 & 8.10 & 5.73 \\
$\mathrm{~T}_{8}$ & 326407.28 & 3.41 & 9.11 & $14.55(60.0 \%)$ & 4.53 & 5.00 & 5.50 & 1.53 \\
$\mathrm{~T}_{9}$ & 152772.53 & 1.97 & 6.50 & $21.10(41.9 \%)$ & 15.43 & 19.00 & 13.40 & 32.18 \\
$\mathrm{~S} . \mathrm{Em} .+$ & 0.001 & 0.005 & 0.162 & 1.247 & 0.346 & 0.568 & 0.227 & 0.394 \\
$\mathrm{CD}(\mathrm{P}<0.05)$ & 0.003 & 0.017 & 0.480 & 3.693 & 1.026 & 1.68 & 0.672 & 1.166 \\
\hline
\end{tabular}

Occurrence of chilli leaf curling and fruit rot was detected throughout the investigation period. The best performance, with a marked reduction in leaf curling and fruit rot and improve fruit quality was observed in drip irrigation with LLDPE mulching (Table 3). The minimum incidence of fruit rot $(5.0 \%)$, leaf curing $(5.5 \%)$ and highest quality score of fruit (9.11) was observed in $T_{8}$ treatment which was closely followed by $\mathrm{T}_{7}$ and $\mathrm{T}_{5}$ treatments where as maximum incidence of fruit rot $(20.02 \%)$ and leaf curling $(15.84 \%)$ was reported in check basin method of irrigation ( $T_{1}$ treatment) whereas minimum quality score (6.50) was observed in $\mathrm{T}_{9}$ treatment. Presence of white fly and weed was observed throughout the investigation period. The minimum population of white flies (4.53 plant $\left.^{-1}\right)$ and weed infestation (1.53 weed $\mathrm{m}^{-2}$ ) was observed in $\mathrm{T}_{8}$ treatment whereas highest incidence of white flies (17.43 plant ${ }^{-1}$ ) and weed infestation (30.03 weed $\mathrm{m}^{-2}$ ) was observed in $T_{1}$ treatment. This is due to the fact that in drip irrigation with mulching significantly reduced additional moisture level in field environment which in turn increase quality of fruits and reduce disease infestation, white fly population as well as it also trim down weed seed germination, growth and development. The increase in quality of fruits was due to the effective utilization of applied nutrients, water and significantly reduced weed growth; disease incidence and increased rate of photosynthesis, sink capacity and accumulated more amounts of dry matter and finally increased quality of fruits and yield. Conventional surface irrigation methods without mulching provide favorable environmental condition for increase insect population and development of disease as well as germinate and develop high density weed plants. The beneficial effect of drip irrigation and black LLDPE mulch in capsicum, tomato and okra was also reported earlier by Horo et al. (2003); Singh (2007); Vankar \& Shinde (2007), Bhardwaj \& Sarolia (2012), Paul et al. (2013).

The combination of raised bed + drip irrigation system with LLDPE mulching is observed to be economical and cost effective as compared with conventional surface irrigation without mulching. Thus, the use of drip irrigation system either alone or in combination with 
mulching, could increase the chilli yield quality of fruits and profitability. It also reduces white fly population, disease incidence (root rot and leaf curling) and minimise with crop weed competition. Drip irrigation with mulching increase water use efficiency by significant reduction in irrigation time ha ${ }^{-1}$. It is concluded that the drip irrigation method with LLDPE mulching is suitable for chilli production in arid and semi arid condition of western Rajasthan.

\section{References}

Agrawal N \& Agrawal S 2005 Effect of drip irrigation and mulches on the growth and yield of banana $c v$. Dwarf Cavendish. Indian J. Hort. 62: 238-240.

Biswas S K, Akanda A R, Rahman M S \& Hossain M A 2015 Effect of drip irrigation and mulching on yield, water-use efficiency and economics of tomato. Plant Soil Environ. 61: 97-102.

Bhardwaj R L \& Sarolia D K 2012 Effect of mulching on crop production under rainfed condition: A Review. Agri. Rev. 34: 188-197.

Horo P, Choudhary B M, Prasad B N \& Kandeyang S 2003 Effect of micro irrigation on growth and yield of tomato in Jharkhand. The Orissa J. Hort. 31: 80-83.

Kumar R, Himanshu Trivedi, Rahul Yadav, Bhagwan Das \& Ankur Singh Bist 2016 Effect of drip irrigation on yield and water use efficiency on Brinjal (Solanum melongena) cv. Pant samrat. Int. J. Engg. Sci. Res. Technol. 5: 7-17.

Panda S C 2004 Mulching. In: Panda S C, Patnaik K K, Mishra J N, Pradhan P C \& Alim M A (Eds.), Training Manual on Precision Farming in Horticulture. PFDC, OUAT, Bhubaneswar.

Panse V G \& Sukhatme P V 1985 Statistical Methods for Agricultural Workers. ICAR, New Delhi, pp.63-100.

Pattanaik S K, Sahu N N, Pradhan P C \& Mohanty M K 2003 Response of Banana to drip irrigation under different irrigation designs. J. Agri. Engg. ISAE 40: 29-34.

Paul J C, Mishra J N, Pradhan P L \& Panigrahi B 2013 Effect of drip and surface irrigation on yield, water use efficiency and economics of capsicum (Capsicum annum L.) grown under mulch and non-mulch conditions in eastern coastal India. European J. Sustainable Dev. 2: 99-108.

Sankar V, Lawande K E \& Tripathy P C 2008 Effect of micro irrigation on growth, yield and water-use-efficiency of onion (Allium cepa) under Western Maharashtra conditions. Indian J. Agri. Sci. 78: 584-588.

Tiwari K N, Mal P K, Singh R M \& Chattopadhya A 1998a Response of Okra to drip irrigation under mulch and non-mulch conditions. Agril. Water Manag. 38: 91-102. 


\title{
Evaluation of stable and non shattering isabgol cultivar - Gujarat isabgol 4
}

\author{
D G Patel, H B Patel*, P T Patel, H Patel \& A U Amin
}

Seed Spices Research Station, Sardarkrushinagar Dantiwada Agricultural University, Jagudan-382 710, Mahesana, Gujarat.

${ }^{*}$ E-mail: hirenpbg@yahoo.co.in

Received 02 November 2017; Revised 10 April 2018; Accepted 28 April 2018

\begin{abstract}
Isabgol growing area was surveyed during 2009-10 and selected genotypes were evaluated in preliminary evaluation trial (PET) during 2010-13 and in large scale varietal trial (LSVT) during 2013-15. It was found that JI-09-21 recorded better growth and yield characters and yield over check Gujarat Isabgol 3. The JI-09-21 did not shatter much even after water dripping and recommended for cultivation as Gujarat Isabgol 4.
\end{abstract}

Keywords: gujarat isabgol 4, isabgol, new variety, non shattering type

Isabgol (Plantago ovata Forsk) is a short duration, more remunerative and medicinally important crop of arid and semiarid regions. In India, it is largely grown in Gujarat, Rajasthan, Madhya Pradesh and Haryana. The area under Isabgol in India during 2014-15 is 1.09 lakh hectares. The production recorded 72 thousand MT with productivity of $660 \mathrm{~kg} \mathrm{ha}^{-1}$. In Gujarat, area mostly falls in Banaskantha, Kachchh and Patan districts with acreage of nine thousand hectare with production and productivity $5000 \mathrm{MT}$ and $556 \mathrm{~kg} \mathrm{ha}^{-1}$, respectively during 2015-16 (Anonymous 2016a). During the last decade, area and production of isabgol has decreased to the tune of $343 \%$ and $281 \%$, respectively, mainly due to problems of seed shattering. At the time of maturity, unseasonal rain or heavy dew leads to failure of the crop which is the fact for reduction of area under Isabgol (Anonymous 2016b). The objective of the study was to evolve non-shattering isabgol cultivars.
Isabgol growing area of Kachchh in Gujarat was surveyed during 2009-10 and subsequently genotypes were evaluated. First three years (2010-11 to 2012-13) 13 genotypes (JI-09-03, 07, $10,13,15,16,20,21,22,23,24,25$ and 26) with check (Gujarat Isabgol -03) were evaluated in preliminary evaluation - trial (PET). During 2013-14 and 2014-15, nine genotypes (JI-08-02, JI-09-07, 13, 16, 20, 21, 22, 24 and 25) along with check (Gujarat Isabgol -03) was tested. The trials were carried out at three different locations viz., Jagudan, Kholwada and Deesa in a randomized block design with three replications.

The stability analysis of variance and stability parameters viz., linear regression coefficient (bi) and deviation from regression $\left(\mathrm{S}^{2} \mathrm{di}\right)$ of genotype means over environment were computed as suggested by Eberhart \& Russell (1966).

Shattering per cent was computed as suggested by Singh et al. (2005) and Chandra (1967). Five 
plants in each replication were selected at maturity stage. Entire spike were dipped in water and then observed for seed shattering from selected plants. The percentage of seed shattering calculated by using a following formula.

Shattering per cent $=[($ Expected seed yield Seed wt. after threshing) / (Expected seed yield)] $\times 100$

Expected seed yield= H.I. x Sun Dry wt. (kg)/ 100

Considering eight trials at three locations for five years, JI-09-21 was recorded higher $(928 \mathrm{~kg}$ $\mathrm{ha}^{-1}$ ) seed yield against $830 \mathrm{~kg} \mathrm{ha}^{-1}$ of Gujarat Isabgol 3 (GI 3), which was $11.78 \%$ higher than GI-3 (Table 1). The new variety named as
Gujarat Isabgol 4 was having more tillers plant $^{-1}(6.0)$, more spikes plant ${ }^{-1}(22.7)$, seeds spike $^{-1}$ (80.7), higher test weight (1.58 gm) and high swelling factor $\left(11.4 \mathrm{cc} \mathrm{g}^{-1}\right)$ than that of check variety GI-3, due to these yield contributing traits GI-4 is having high seed yield potential (Table 3 ). The similar kind of results also obtained by Prajapati et al. (2011).

Gujarat Isabgol 4 recorded high mean with regression coefficient (bi) near unity and deviation from regression $\left(\mathrm{S}^{2} \mathrm{di}\right)$ around zero for seed yield, indicating GI-4 has average responsiveness and are highly stable over environments (Table 2).

The new culture has compact spike and did not separate easily even after dipping in water. Only $7.25 \%$ seeds shattered after dipping in water.

Table 1. The comparative yield performance $\left(\mathrm{kg} \mathrm{ha}^{-1}\right)$ of JI-09-21 (GI 4) over different locations

\begin{tabular}{|c|c|c|c|c|c|c|c|c|}
\hline \multirow[t]{2}{*}{ Year } & \multirow[t]{2}{*}{ Trial } & \multicolumn{2}{|c|}{ Yield $\left(\mathrm{kg} \mathrm{ha}^{-1}\right)$} & \multirow[t]{2}{*}{ IOC (\%) } & \multirow[t]{2}{*}{ Rank } & \multirow[t]{2}{*}{ S.Em. \pm} & \multirow{2}{*}{$\begin{array}{c}C D \\
(\mathrm{P}<0.05)\end{array}$} & \multirow[t]{2}{*}{ C.V. $\%$} \\
\hline & & JI-09-21 & GI-3 & & & & & \\
\hline \multicolumn{9}{|l|}{ Jagudan } \\
\hline $2010-11$ & PET & 1014 & 894 & 13.42 & $1 / 14$ & 56 & 167 & 10.80 \\
\hline 2011-12 & PET & 1078 & 948 & 13.71 & $1 / 14$ & 49 & 150 & 10.39 \\
\hline $2012-13$ & PET & 907 & 863 & 5.10 & $2 / 14$ & 51 & 155 & 9.47 \\
\hline 2013-14 & LSVT-II & 946 & 874 & 8.24 & $1 / 10$ & 52 & 155 & 11.55 \\
\hline \multirow[t]{2}{*}{ 2014-15 } & LSVT-II & 949 & 812 & 16.87 & $1 / 10$ & 50 & 148 & 11.12 \\
\hline & Mean (5) & 979 & 878 & 11.46 & - & - & - & - \\
\hline \multicolumn{9}{|c|}{ Kholwada } \\
\hline 2013-14 & LSVT-II & 878 & 769 & 14.17 & $1 / 10$ & 52 & 154 & 13.78 \\
\hline \multirow[t]{2}{*}{ 2014-15 } & LSVT-II & $852 *$ & 759 & 12.25 & $1 / 10$ & 31 & 91 & 9.56 \\
\hline & Mean (2) & 865 & 764 & 13.22 & - & - & - & - \\
\hline \multicolumn{9}{|l|}{ Deesa } \\
\hline 2014-15 & LSVT-II & 799 & 722 & 10.66 & $3 / 10$ & 73 & 215 & 14.79 \\
\hline \multicolumn{2}{|c|}{ Overall Mean (8 trials).... } & 928 & 830 & 11.78 & - & - & - & - \\
\hline \multicolumn{2}{|c|}{ Superiority over check.... } & $8 / 8$ & - & - & - & - & - & - \\
\hline
\end{tabular}

Table 2. Stability Analysis for seed yield in Isabgol

\begin{tabular}{lccc}
\hline Variety & Yi (mean seed yield $)\left(\mathrm{kg} \mathrm{plot}^{-1}\right)$ & bi(reg. coeff.) & S $_{\text {di }}$ (mean Sq. dev.) \\
\hline JI -09-21(GI 4) & 0.82 & 0.94 & 0.00 \\
GI-3 (Ch) & 0.42 & 0.80 & 0.00 \\
Mean & 0.39 & - & \\
\hline
\end{tabular}


Table 3. Comparative yield and quality attributes of JI -09-21 (GI 4)

\begin{tabular}{lcc}
\hline Character & \multicolumn{2}{c}{ Mean } \\
\cline { 2 - 3 } & JI -09-21 (GI 4) & GI 3 \\
\hline Days to flowering & 63 & 104 \\
Days to maturity & 102 & 31.3 \\
Plant height (cm) & 31.0 & 5.0 \\
No. of tillers plant ${ }^{-1}$ & 6.0 & 20.2 \\
No. of spikes plant ${ }^{-1}$ & 22.7 & 4.5 \\
Spike length (cm) & 4.7 & 76.4 \\
No. of seeds spike ${ }^{-1}$ & 80.7 & 1.542 \\
1000 grain weight (g) & 1.579 & 9.1 \\
Swelling factor $\left(\mathrm{cc} \mathrm{g}^{-1}\right)$ & 11.4 & \\
\hline
\end{tabular}

Table 4. Effect of water dipping on shattering of isabgol seed

\begin{tabular}{lcccccccc}
\hline Variety & \multicolumn{2}{l}{ Without Dipping } & H.I $\%$ & \multicolumn{3}{c}{ Dipping in Water (Average of } & four sample) \\
\cline { 2 - 5 } & $\begin{array}{c}\text { Dry wt. } \\
(\mathrm{kg})\end{array}$ & $\begin{array}{c}\text { Seed wt. } \\
(\mathrm{kg})\end{array}$ & & & $\begin{array}{c}\text { Dry wt. } \\
\text { (initial) } \\
(\mathrm{kg})\end{array}$ & $\begin{array}{c}\text { Sun dry } \\
\text { wt. } \\
(\mathrm{kg})\end{array}$ & $\begin{array}{c}\text { Seed wt. } \\
\text { after } \\
\text { threshing } \\
(\mathrm{kg})\end{array}$ & $\begin{array}{c}\text { Shattering } \\
\text { of seeds } \\
(\%)\end{array}$ \\
\hline GI 4 (JI-09-21) & 1.027 & 0.175 & 17.03 & & 0.894 & 0.731 & 0.115 & 7.25 \\
GI 3 & 0.959 & 0.158 & 16.47 & 1.038 & 0.811 & 0.037 & 70.07 \\
\hline
\end{tabular}

GI-4 recorded $89.67 \%$ less shattering than that of check variety, which revealed that Gujarat Isabgol 4 was non shattering in habit as compared to Gujarat Isabgol 3 which is prone to high seed shattering. The post dipped seed weight of GI 4,-was $0.115 \mathrm{~kg}$ threshed seeds, which was $96 \%$ higher than that of the post dipped seed yield of GI-3 (0.037 kg threshed seeds) (Table 4). Hence, Gujarat Isabgol 4 recommended for cultivation.

\section{Acknowledgments}

The authors are thankful to Prof. M.M. Patel and Prof. P.R. Patel, Assistant Research Scientist, SDAU, Kholwada and Dr. S.K. Jain, Assistant Research Scientist, SDAU, Deesa, for technical support and to conduct experiment.

\section{References}

Anonymous 2016a District wise area and production of spices crops in Gujarat State.
Directorate of Agriculture, Gujarat State, Gandhinagar.

Anonymous 2016b Spices exports go up by 15 per cent in value. Spices India. A Journal Published by Spices Board, Cochin. 1: 7.

Chandra V 1967 Studies in cultivation of Plantago ovata Forsk. Indian J. Pharm. 29: 331-332.

Prajapati D B, Patel K P \& Ravindrababu Y 2011 Gujarat Isabgol-3 a promising cultivar of Isabgol. Int. J. Forest Crop Improv. 2: 81-84.

Eberhart S A \& Russell W A 1966 Stability parameters for comparing varieties. Crop Sci. 6: 36-40.

Singh R N, Patel K V \& Desai N N 2005 Value addition through processing of Isabgol. In: Tikka S B S, Arha M D, Jaimini S N, Tajane K $\mathrm{R}$ \& Patel N B (Eds.). Abstr. National Symposium on Stress Management. 11-13 April, S. D. Agriculture University, S. K. Nagar, Gujarat (pp.147), Gujarat Society of Genetics \& Plant Breeding, S. K. Nagar. 